\title{
Ethnomedicine in Himalaya: a case study from Dolpa, Humla, Jumla and Mustang districts of Nepal
}

\author{
Ripu M Kunwar ${ }^{1}$, Bal K Nepal ${ }^{1}$, Hari B Kshhetri ${ }^{1}$, Sanjeev K Rai ${ }^{1}$ and \\ Rainer W Bussmann*2
}

Address: ${ }^{1}$ Center for Biological Conservation, Nepal and ${ }^{2}$ University of Hawaii, USA

Email: Ripu M Kunwar - ripu@wlink.com.np; Bal K Nepal - ripu@wlink.com.np; Hari B Kshhetri - ripu@wlink.com.np; Sanjeev K Rai - ripu@wlink.com.np; Rainer W Bussmann* - bussmann@hawaii.edu

* Corresponding author

Published: 02 June 2006

Journal of Ethnobiology and Ethnomedicine 2006, 2:27 doi:10.1186/1746-4269-2-27

This article is available from: http://www.ethnobiomed.com/content/2/I/27

(c) 2006 Kunwar et al; licensee BioMed Central Ltd.

This is an Open Access article distributed under the terms of the Creative Commons Attribution License (http://creativecommons.org/licenses/by/2.0), which permits unrestricted use, distribution, and reproduction in any medium, provided the original work is properly cited.
Received: 17 March 2006

Accepted: 02 June 2006

\begin{abstract}
Traditional plant use in Nepal has been documented for millennia. The importance of plants as medicine has not diminished in any way in recent times, and traditional medicines are still the most important health care source for the vast majority of the population.

This paper examines the ethnobotany and traditional use of plants extracted from the vulnerable alpine zone in the Dolpa, Humla, Jumla and Mustang districts of Nepal.

The results of this ethnobotanical study indicate that a very large number of plant species is used as traditional medicines. There were 107, 59, 44 and 166 species of ethnomedicinal importance in surveyed areas of Dolpa, Humla, Jumla and Mustang district respectively. Of these, 84 common species, used at least in two districts, were selected to enumerate their ethnomedicinal properties. The 84 species belonged to 75 genera and 39 families.

The commonest species in this pharmacopoeia were: Allium wallichii, Cordyceps sinensis, Dactylorhiza hatagirea, and Rheum australe. A total of 21 species were most common in three districts and 59 in two districts. The genera Aconitum, Allium, Arisaema, Berberis, Corydalis, Gentiana, Hippophae, Juniperus and Rhododendron each possessed two species with ethnomedicinal use. Labiatae was the most medicinally important family with five species used, followed by Araceae, Compositae, Liliaceae, Polygonaceae, Ranunculaceae, Scrophulariaceae and Umbelliferae, each contributing four species.
\end{abstract}

\section{Background}

The use of plants and plant products as medicine can be traced as far back as the beginning of human civilization. The earliest record of medicinal plant use in the Himalayas is found in the Rigveda. This work was written between $4500 \mathrm{BC}$ and $1600 \mathrm{BC}$, is supposed to be the oldest repository of human knowledge and describes 67 plants [1]. After the Rigveda, Ayurveda (the foundation of science of life and the art of healing of Hindu culture) describes the medicinal importance of 1200 plants. The Charak or Caraka Samhita (900 BC) and Susruta Samhita (500 BC) enumerate the art of surgery, therapeutics and medicines in detail on the basis of Atharvaveda [2]. The knowledge of using these systems was accessed by Nepali Vaidhyas and Kabirajs as early as about 879 AD [3]. Therefore, the Ayurvedic physicians were incorporating medicinal plants 
in traditional Ayurvedic formulations from early on and the Ayurvedic system is reputed all over the Indian subcontinent since time immemorial $[4,5]$. In addition to the Ayurvedic system, a large number of plants are also used in different other traditional health systems, including Homeopathic, Amchi (practice of Tibetan traditional medicine), Chinese [6,7], and folklore [8]. Plants for health care were also processed, exchanged and form part of secular trade systems [9-11]. The use of locally available medicinal plants is often an economically inevitable alternative to expensive western medicines [12].

A hand written herbal encyclopedia Bir Nighantu or Bir pharmacopoecia was compiled by Pandit Ghana Nath Devkota under the instruction of Bir Samser, the former prime minister of Nepal (1885-1901 AD). An elaborated account is found in Nepali Nighantu written by Kosh Nath Devkota published by the Royal Nepal Academy in 1969 [5]. This encyclopedia covers 750 plants in detail and is probably the first written effort towards a compilation of the traditional knowledge about medicinal plants of the country. The earliest published work dealing with the medicinal plants of Nepal was published in 1955 [13].

Medicinal plants from Nepal were traded across the borders to Tibet as early as 600 AD [14]. Presently, over 90\% of the total export from Nepal is to India and mostly in crude form [15]. Conservative estimates of the annual Nepalese alpine and sub-alpine medicinal plant vary from 480 to 2500 tons, with a total harvest value of US\$ 0.8 3.3 million [16]. Presently the value is much higher already (Table 1).

Medicinal and aromatic plants are local heritage of global importance [17]. Total $60 \%$ of the population of world and $80 \%$ of the population in developing countries rely on traditional medicine, mostly plant drugs, for their primary health care needs [18]. An account of $70 \%$ of the population of India [19], 80\% of Pakistan [20] and 80\% of Nepal are dependent on traditional plant based medicines. Medicinal and aromatic plants help in alleviating human suffering and are widely used as additives, bever- ages, cosmetics, sweeteners, bitters, spices, dying agents and insecticides. They are found throughout Nepal, from the plains to the high Himalayas, with the greatest concentration in the tropical and arid zones. Nepal recognizes about 1624 plant species as having medicinal and aromatic values, Sri Lanka about 1400, India about 2500 and China about $5000[17,21,22]$. A tentative list of the alpine flora of the Nepal Himalaya consists of 1227 species in 317 genera [23] including 114 and 45 medicinal plants respectively from the subalpine and alpine zones [1]. The Himalayan region shows the highest richness for endemic species and medicinal herbs [24].

Due to changing life, perception and lifestyle changes of the forest dwellers, as well as commercialization and socio-economic transformation on a global scale, there is a general observation that the plants are exacerbated and that indigenous knowledge on resource use is being degraded severely $[25,26]$. Due to lack of organized, sustainable cultivation based on scientific data and lacking awareness of social factors influencing plant use and market, no proper management of traditional medicines is in place, and the numbers of these plants are decreasing at an alarming rate [27]. Medicinal herbs are regarded as free commodity (zero private cost) to be collected from nature [28]. Ethnomedicinal studies are a suitable source of information regarding useful medicinal plants that can be targeted for domestication and management [29]. In this context the human interferences is considered an essential ecological factor for managing the plant resources and ethnobotanical knowledge. The present study therefore aims at highlighting the ethnomedicinal uses of plant resources of the Himalaya regions.

\section{Study area}

The study area comprises Chandannath, Depalgaun, Garjyang and Khalanga villages of Jumla district; Chhuksang, Samar and Lomanthang villages of Mustang district; Mimi, Melcham and Dharma villages of Humla district and Dunai, Juphal, Raha, Tripurakot and Phoksundo villages of Dolpa district. Some villages of Dolpa and Mustang districts respectively represent the protected areas:

Table I: Amount of important medicinal plants exported from Nepal (in tons)

\begin{tabular}{|c|c|c|c|c|c|c|c|}
\hline Species & 1999 & 2000 & 2001 & 2002 & 2003 & 2004 & Average \\
\hline Acorus calamus & 20 & 12 & 11 & 9 & 6 & 10 & $\mathrm{II}$ \\
\hline Cordyceps sinensis & & & & .0031 & .0045 & .0756 & .0277 \\
\hline Delphinium himalayai & .5 & 2.1 & 6.4 & 12 & 2 & 2 & 4.3 \\
\hline Morchella conica & & & & .93 & 5.1 & I.I & 2.4 \\
\hline Nardostachys grandiflora & 29 & 83 & 46 & 254 & 45 & 208 & 111 \\
\hline Neopicrorhiza scrophulariiflora & 35 & 46 & 39 & .2 & .3 & 5.2 & 21 \\
\hline Valeriana jatamansii & 33 & 34 & 20 & 28 & 42 & 88 & 41 \\
\hline Zanthoxylum armatum & 355 & 361 & 533 & 1006 & 650 & 365 & 545 \\
\hline
\end{tabular}

Source: Department of forest, Ministry of forest and soil conservation, Kathmandu, Nepal 
Shey-Phoksundo National Park and Annapurna Conservation Area. All the areas are above 2200 masl and extend up to 6800 masl.

The major ethnic groups of the study area are Gurung, Shahi, Sherpa, Rokaya, Thakuri, Kshetri, Bhramin, Sarki, etc. They are Indo-Aryan and Tibeto-Burmans, speaking Nepali, and some Tibetan dialects as Kham. Most of them practice the Hindu and Buddhist religion, and have traits reflecting a mix of Tibeto-Burman and Indo-Aryan cultures. Agricultural land use focuses on cultivation of wild rice (Chino, Kaguno), buckwheat, potato, etc. on less fertile land.

The cultural and social control of high-altitude medicinal plants was studied in communities living inside the SheyPhoksundo National Park [30]. The local economy relies on agriculture, grazing and seasonal trade. Due to low production, most of the people rely on the collection of wild medicinal plants for subsistence. They are engaged particularly in collecting medicinal herbs and raw food items as part of their traditional ventures [28]. However the collection in the Himalaya region is being increasingly driven by commercial demands from wider market [24].

\section{Methods}

Ethnomedicinal data for wild plants traditionally used by rural inhabitants of the study area were recorded during field visits, and vouchers of the encountered plant species were collected. A total of five field visits were conducted: one in each district and two in Dolpa district (July 2001 and May 2003 for Dolpa district, September-October 2001 for Humla district, November-December 2004 for Jumla district, July-August 2003 for Mustang district). Surveys, personal interviews and group discussions as Participatory Rural Appraisal (PRA) technique [31] were applied to reveal the specific information about traditional healing practices and ethnomedicinal uses of plants. Altogether 480 (160 in Dolpa district, 110 in Humla district, 115 in Jumla district, and 95 in Mustang district) local healers, experienced aged persons and Amchi were consulted for information on folk uses of plants, which was further authenticated by cross-checking with key informants. The key informants were Amchi and experienced older persons.

Plant specimens were collected following Cunningham [32] and identified in the field up to species level whenever possible. The nomenclature follows [33-39]. All species were collected, and compared to vouchers at Tribhuvan University Central Herbarium (TUCH), and deposited in TUCH with duplicates in the King Mahendra Trust for Nature Conservation/Annapurna Conservation Area Project, Nepal. The species presented here include the most important of the total ethnomedicinal plant spe- cies, with all samples found in at least for two districts included.

\section{Results and discussion}

Among the 529 useful plant species recorded from Dolpa district so far, more than 400 species are medicinal [40]. Of the total medicinal plant species, the most important 100 species were recorded by Lama et al. [41] and 58 species were encountered from Dunai, Juphal, Majhphal, Sahartara and Suu villages of Dolpa district [42]. The present study states that there are 107, 59, 44 and 166 species of ethnomedicinal importance in surveyed areas of Dolpa, Humla, Jumla and Mustang district respectively. Of these, 84 common species in terms of distribution and folk use were selected to enumerate their ethnomedicinal properties. The 84 species belong to 75 genera and 39 families. Allium wallichii, Cordyceps sinensis, Dactylorhiza hatagirea, and Rheum australe were especially common in study area. A total of 21 species were most common in three districts and 59 in two districts. The genera Aconitum, Allium, Arisaema, Berberis, Corydalis, Gentiana, Hippophae, Juniperus and Rhododendron each possessed two species with ethnomedicinal use. Labiatae was the most medicinally important family with five species used, followed by Araceae, Compositae, Liliaceae, Polygonaceae, Ranunculaceae, Scrophulariaceae and Umbelliferae, each contributing four species.

The plant parts used for medicinal preparations were bark, flower, fruit, leaf, root, rhizome, tuber, seed, shoot, resin, wood, etc. (Table 2). In some cases the whole plant was utilized. The most frequently utilized plant part was the root/rhizome/tuber $(26.15 \%)$, followed by leaf $(23.84 \%)$ and flower and fruit $(21.53 \%)$. The high importance of the underground part was attributed to having high concentrations of bioactive compounds [43]. The largest number of remedies $(21.70 \%)$ were used to treat respiratory tract infections (asthma, cold, cough, fever, headache, pneumonia, sinusitis, etc.) while $19.92 \%$ remedies were taken to cure gastro-intestinal problems (cholera, gastritis, intestinal pain, stomachache, etc.), 7.82\% remedies were used for skeleto-muscular problems (arthritis, fracture, rheumatism, sprain, swelling, etc.) and dermatological problems (scabies, skin disease, etc.), $4.27 \%$ for ENT (ear, nose and throat) problems, and to a lesser extent for cuts and wounds, dental, cardiovascular system, circulatory system, etc. Plants were also important as tonic, astringent, anthelminthic, insecticide, incense stick, appetite stimulant, antidote, etc. The preparation methods included decoction, juice, oil, paste, powder, extract, smoke, and raw (unprocessed). The majority of remedies were prepared as juice (29.52\%), followed by raw $(19.04 \%)$, paste $(16.19 \%)$, extract $(13.33 \%)$, decoction $(11.42 \%)$, powder $(6.66 \%)$, etc. 
Table 2: Illness, plant parts in use and mode of preparations

\begin{tabular}{llll}
\hline SN & IIIness & Plant parts in use & Mode of preparations \\
\hline 1 & Fever (26) & Root/rhizome/tuber (34) & Juice (3I) \\
2 & Cough and cold (15) & Leaf $(31)$ & Raw $(20)$ \\
3 & Indigestion (12) & Flower and fruit (28) & Paste $(17)$ \\
4 & Diarrhea (II) & Whole plant (10) & Extract $(14)$ \\
5 & Tonic (10) & Seed (8) & Decoction $(12)$ \\
6 & Skin disease (10) & Shoot (7) & Powder (7) \\
7 & Cuts and wounds (10) & Bark (7) & Oil (3) \\
8 & Appetite stimulant (9) & Wood (3) & Smoke $(1)$ \\
9 & Headache (9) & Resin (2) & \\
10 & Dysentery (9) & & \\
\hline
\end{tabular}

Figure in parenthesis represents the number of species in use

Since the populations of the study areas belong to different ethnic groups, there are disparities and commonalities in the way of employing the same plant species and preparing remedies. Jurinea dolomiaea is used as incense and ethnomedicine for diarrhea and stomachache in Dolpa district, whereas it is employed only as incense in Humla district. Seed of Juniperus indica is eaten in Dolpa to get relief from kidney problems, whereas its leaf juice is taken for cough, cold and paralysis in Humla district. Fruit juice and seed coat of Juglans regia are employed to treat to wounds in Jumla district while the paste from bark is applied for arthritis and hair growth in Dolpa district. A complete list of all plants with scientific and vernacular names, usage, collection number and location is given in the additional file 1.

The observations from the present survey need to be substantiated with pharmaco-chemical studies in order to evaluate the effectiveness of the herbs and preparations used. However, for some species, there is evidence in the literature that the mode of use by the local people is likely to be effective. Application of rhubarb root paste in diarrhea and dysentery coincides to the pharmaco-chemical properties because of the purgative and astringent effects [44].

Medicinal and aromatic plants play a vital role in the life support systems of contemporary civilization by serving the purpose of maintaining good health and well being of mankind. The plants in the Himalayas grow very slowly and cannot live elsewhere, and have substantial importance to the hill and mountain peasants. Despite gradual socio-cultural transformation in the Himalaya regions [45], local communities still possess invaluable knowledge of plants and their uses. Large numbers of people are engaged in collection of medicinal and aromatic plants. It was found that herders are the main collectors of high altitude medicinal plants, which they harvest from alpine meadows and pastures [46]. Though local people do not have much scientific knowledge on sustainable harvesting of medicinal plants, they are familiar with habitat specificity and biology of plants [47]. Ethnoecological knowledge and practices of a given area are important to consider in sustainable management of Himalayan medicinal plant resources [48].

The plants are widely used as resource for grazing in the Himalayas. Rotational grazing of livestock and selective harvesting mainly applied by Amchis were only the sustainable management approaches aimed at constraining pressures. Though the practices were noticeable in all districts, former was important Dolpa, Jumla and Humla districts and the later was most in Dolpa and Mustang districts.

\section{Conclusion}

In the Himalaya, most of the people follow Buddhism and Bon religion and they have strong belief and faith on traditional herbal medicinal practice for health treatment and therefore, the conservation of medicinal plants is not only vital to their livelihood but also has immense cultural significance to them [49]. Medicinal plants are now found growing sporadically in forests/pastures as well as in village groves. Uses of the plants and their produce/ products from nearby forests by rural people are common because there is no alternative method to adopt. Forests have commercially exploitable medicinal species, which if manage properly can serve a sustainable income sources for local communities. An urgent need, therefore for conservation of medicinal plant species and their habitats and indigenous knowledge, is required. Ethnoecological knowledge, plant life forms and growth patterns are imperative to consider for management of Himalayan medicinal herbs [50].

\section{Declaration of competing interests}

The author(s) declare that they have no competing interests. 


\section{Authors' contributions}

All authors share the contributions to this MS. The fieldwork for data collection was carried out by Ripu M Kunwar, Bal K Nepal, Hari B Kshhetri and Sanjeev K Rai. Data analysis and manuscript preparation were conducted by all authors.

\section{Additional material}

\section{Additional file 1}

List of plants, vernacular names, indigenous uses and distribution Click here for file

[http://www.biomedcentral.com/content/supplementary/17464269-2-27-s1.pdf]

\section{Acknowledgements}

The authors are grateful to WWF Nepal program; Tourism for Rural Poverty Alleviation Program, Nepal; King Mahendra Trust for Nature Conservation Nepal; Asia Network for Sustainable Agriculture and Bioresources, Kathmandu and Herbs Production and Processing Co. Ltd, Nepal for their supports for field studies. Thanks are also due to P Sapkota, M Pokharel, B Shrestha, N Subedi and L Kunwar for their support. Dr SK Ghimire, Tribhuvan University, Nepal is acknowledged for critical comments. Local people are acknowledged who gave invaluable time and cooperation during field visits.

\section{References}

I. Malla SB, Shakya PR: Medicinal Plants of Nepal. In Nepal-Natures' Paradise Edited by: Majupuria TC. White Lotus Ltd, Bangkok; 1984:26|-297.

2. Nambiar VPK: Improved Harvesting, Processing and Storage of Medicinal Plants: Their Role in Conservation and Quality of Plant Based Drugs. In Proc of Sharing Local and National Experience in Conservation of Medicinal and Aromatic Plants in South Asia Edited by: Bhattarai N, Karki M. HMGN, IDRC and MAPPA; 2002:42-45.

3. IUCN Nepal: National Register of Medicinal Plants. Ministry of Forests and Soil Conservation Nepal and IUCN Nepal. Kathmandu, Nepal; 2000

4. Olsen CS, Helles F: Medicinal Plants, Markets and Margins in the Nepal Himalaya: Trouble in Paradise. Mountain Res Dev 1997, I 7(4):363-374.

5. IUCN Nepal: National Register of Medicinal and Aromatic Plants (revised and updated). In IUCN Nepal Kathmandu, Nepal; 2004:202.

6. Gurung TN, Lama GG, Shrestha KK, Craig S: Medicinal Plants and Traditional Doctors in Shey-Phoksundo National Park and Other Areas of Dolpa District, Nepal. In WWF Nepal Program Volume 26. Kathmandu, Nepal Report series; 1996.

7. Thomas YA, Lama YC, Ghimire SK: Health Care Development and Medicinal Plant Conservation at Shey-Phoksundo National Park, Nepal. In Proc of Sharing Local and National Experience in Conservation of Medicinal and Aromatic Plants in South Asia Edited by: Bhattarai N, Karki M. HMGN, IDRC and MAPPA; 2001:7I-92.

8. Kunwar RM: Case Studies of Impacts of SAGUN Program Implementation in Shey-Phoksundo National Park and Buffer Zone Area, Dolpa, Nepal. In WWF Nepal Program Kathmandu, Nepal; 2006. 40+viiip

9. Dobremez JF: Le Nepal, Ecologie et Biogeographic. Eds CNRS, Paris; 1976.

10. Fisher JF: Trans-Himalayan Traders: Economy, Society and Culture in North-West Nepal. Motilal Banarasidass Publishers, Delhi, India; 1987.

II. Edwards DM: NTFPs from Nepal: Aspects of the Trade in Medicinal and Aromatic Plants. In FORESC monograph Volume I/
96. Forest Research and Survey Center. MoFSC, Kathmandu, Nepal; 1996.

12. Bussmann RW: Ethnobotany and Biodiversity Conservation. In Modern Trends in Applied Terrestrial Ecology Edited by: Ambasht RS, Ambasht NK. Kluwer Publishers; 2002:345-362.

13. Banerji ML: Some Edible and Medicinal Plants from East Nepal. J Bombay Nat Hist Soc 1955, 53: I53-I 56.

14. Sung W, Yiming L: Illegal Trade in the Himalayas. In Ecoregional Cooperation for Biodiversity Cooperation in the Himalayas ICIMOD and WWF: 1998.

15. Bhattarai NK: Biodiversity: People Interface in Nepal. In Medicinal Plants for Forest Conservation and Health Care. Non-wood Forest Product Series Volume II. Food and Agriculture Organization of the United Nations, Rome, Italy; 1997:78-86.

16. Olsen CS, Larsen HO: Alpine Medicinal Plant Trade and Himalayan Mountain Livelihood Strategies. Geogr J 2003, I69(3):243-254.

17. Purohit SS, Vyas SP: Medicinal Plant Cultivation: A Scientific Approach. Agrobois, India; 2004:624.

18. Shrestha PM, Dhillion SS: Medicinal Plant Diversity and Use in the Highlands of Dolakha District, Nepal. J Ethnopharm 2003, 86:81-96.

19. Gadgil M, Rao PRS: Nurturing Biodiversity: An Indian Agenda. Center for Environment Education, Ahamdabad, India; 1998.

20. Ahmad Z, Ghafoor A: Resource Base and Conservation Strategies of MAPs in Pakistan. In Sharing Local and National Experience in Conservation of Medicinal and Aromatic Plants in South Asia Edited by: Bhattarai N, Karki M. HMGN, IDRC and MAPPA; 2002:105-109.

21. Shrestha KK, Tiwari NN, Ghimire SK: Medicinal and Aromatic Plants Database of Nepal (MAPDON). Proc of Nepal-Japan Joint Symposium on Conservation and Utilization of Himalayan Medicinal Plant Resources 2000:53-74.

22. Chaudhary RP: Biodiversity in Nepal: Status and Conservation. In Know Nepal Series Volume 17. Tecpress Books, Thailand; 1998:324.

23. Obha H: The Alpine Flora of the Nepal Himalaya: An Introductory Note. In The Himalayan Plants Edited by: Obha H, Malla SB. The University Museum; 1988:19-46.

24. Kunwar RM, Duwadee NPS: Ecology and Economy of NTFPs in Nepal: A Case Study from Dolpa and Jumla Districts, Nepal. Botanica Orientalis 2003, 3:89-97.

25. Gadgil M, Birkes F, Folkes C: Indigenous Knowledge of Biodiversity Conservation. Ambio 1993, 22:15I-160.

26. Silori CS, Rana AR: Indigenous Knowledge on Medicinal Plants and Their Use in Narayan Sarovar Sanctuary, Kachchh, India. Ethnobotany 2000, 12:1-7.

27. Kunwar RM, Duwadee NPS: Ethnobotanical Notes on Khaptad National Park, Far Western Nepal. Himalayan J Sci 2003, I(I):25-30.

28. Kunwar RM: Some Threatened MAPs: Status, Trade and Management Practice in Dolpa District, Nepal. Nat Hist Mus J 2002, 21:173-186.

29. Njoroge GN, Bussmann RW, Gemmill B, Newton LE, Ngumi VW: Utilization of Weed species as Source of Traditional Medicines in Central Kenya. Lyonia 2004, 7(272-87 [http://www.lyo nia.org/downloadPDF.php?pdfID=2.3|4.I]

30. Thomas YA, Lama YC, Ghimire SK: Medicinal Plants within the Context of Pastoral Life in the Village of Pungmo, Dolpo, Nepal. In Proc of Strategic Innovations for Improving Pastoral Livelihoods in the Hindu-Kush Himalayan Highlands Volume 2. Edited by: Richard C, Hoffmann K. ICIMOD, Kathmandu, Nepal; 2004:108-128.

3I. Martin GJ: Ethnobotany: People and Plants Conservation Manual. Chapman and Hall, London; 1995.

32. Cunningham AB: Applied Ethnobotany, People, Wild Plant Use and Conservation. Earthscan Publishing Ltd, London and Sterling VA; 200I:300.

33. Stainton A, Polunin O: Flowers of the Himalaya. Oxford University Press, New Delhi, India; 1998:580.

34. Stainton A: Flowers of the Himalaya, A Supplement. Oxford University Press, New Delhi, India; 1988:86.

35. Hara H, Stearn WT, Williams LH]: An Enumeration of the Flowering Plants of Nepal I. British Museum (Natural History), London; 1978.

36. Hara H, Williams LH]: An Enumeration of the Flowering Plants of Nepal II. British Museum (Natural History), London; 1979. 
37. Hara H, Chater AO, Williams LHJ: An Enumeration of the Flowering Plants of Nepal III. British Museum (Natural History), London; 1982.

38. Rajbhandari KR: Ethnobotany of Nepal. Ethnobotanical Society of Nepal C/O Central Department of Botany, Tribhuvan University, Kirtipur, Kathmandu Nepal; 200I.

39. Joshi K, Joshi SD: Genetic Heritage of Medicinal and Aromatic Plants of Nepal Himalayas. Buddha Academic Publisher and Distributors Pvt. Ltd. Kathmandu, Nepal; 200I.

40. Ghimire SK, Thomas YA: Approach to in-situ Conservation of Threatened Himalayan Medicinal Plants: A Case Study from Shey-Phoksundo National Park, Dolpa, Nepal. In Proc of the Regional Workshop on Wise Practice and Experience Learning in Conservation and Management of Himalayan Medicinal Plants Kathmandu, Nepal. HMGN, WWF Nepal, IDRC, PPI:209-232. Dec I5-20, 2002

4I. Lama YC, Ghimire SK, Thomas YA: Medicinal Plants of Dolpo: Amchi's Knowledge and Conservation. WWF Nepal Program, Kathmandu, Nepal; 200I:150.

42. Kunwar RM, Adhikari N: Ethnomedicine of Dolpa district, Nepal: The Plants, Their Vernacular Names and Uses. Lyonia 2005, 8(I):41-47.

43. Moore PD: Trials in bad taste. Nature 1994, 370:410-4II.

44. Reynolds JEF, ed: Martindale: the Extra Pharmacopoeia. 28th edition. The Pharmacoceutical Press. London; 1982.

45. Kunwar RM, Sharma SP: Quantitative Analysis of Tree Species in Two Community Forests of Dolpa District, Mid-West Nepal. Himalayan J Sci 2004, 2(3):23-28.

46. Oli BR, Nepal BK: NTFPs from Kangchenjunga Conservation Area: Aspects of Trade and Market Opportunities. WWF Nepal Program 2003. 72+39p

47. Nepal BK, Sapkota PP: Resource Analysis and Indigenous Knowledge on Plant Use: A Case Study of Humla District, Nepal. Nepal Journal of Plant Sciences 2005, I:57-63.

48. Ghimire SK, Mc Key D, Thomas YA: Heterogeneity in Ethnoecological Knowledge and Management of Medicinal Plants in the Himalayas of Nepal: Implications for Conservation. Ecology and Society 2004, 9(36 [http://www.ecologyandsociety.org/vol9/ iss $3 /$ art6/].

49. Ghimire SK, Lama YC, Tripathi GR, Schmitt S, Thomas YA: Conservation of Plant Resources, Community Development and Training in Applied Ethnobotany at Shey-Phoksundo National Park and its Buffer Zone area, Dolpa. WWF Nepa Program \& People and Plants Initiative 2001:230.

50. Ghimire SK, Mc Key D, Thomas YA: Conservation of Himalayan Medicinal Plants: Harvesting Patterns and Ecology of Two Threatened species. Nardostachys grandiflora and Neopicrorhiza scrophulariiflora 2005, I 24:463-475
Publish with Bio Med Central and every scientist can read your work free of charge

"BioMed Central will be the most significant development for disseminating the results of biomedical research in our lifetime. "

Sir Paul Nurse, Cancer Research UK

Your research papers will be:

- available free of charge to the entire biomedical community

- peer reviewed and published immediately upon acceptance

- cited in PubMed and archived on PubMed Central

- yours - you keep the copyright
BioMedcentral 